\title{
Personality profiles of meaning-building strategies
}

\author{
Irina Abakumova ${ }^{1}$, Evgeny Pronenko ${ }^{2}$, and Mikhail Godunov ${ }^{3, *}$ \\ 1 Don State Technical University, Faculty "Psychology, Pedagogy and Defectology", \\ 344000 Rostov-on-Don, Russia \\ ${ }^{2}$ South Federal University, Department of General and Educational Psychology, 344006 \\ Rostov-on-Don, Russia \\ ${ }^{3}$ Educational and Methodical Center «Tempus», 344037 Rostov-on-Don, Russia
}

\begin{abstract}
Meaning formation strategies are one of the integral regulators of modern human activity. To model semantic regulation, two polar strategies of semantic formation are considered: adaptive and developing. The sphere of personal meanings is in mutual agreement with the personality traits manifested in interactions. The article presents the results of empirical identification of polar semantic strategies profiles based on semantic scales of personality traits. We studied a sample $(n=145)$ with gradations by age, gender, and occupation. Both differences and similarities in the profiles of polar semantic strategies were established. This indicates the dynamics of the world image of the experiencing subject, which reflects the different effects of strategies for the meanings formation.
\end{abstract}

\section{Introduction}

In modern versions of activity-semantic approaches, semantic regulation is an integral mechanism for achieving the state of acme. Among the multifaceted processes taking place in the semantic sphere of the experiencing subject, the formation of meanings, their consolidation and actualization occupies an important place. These processes of meanings system regulation occur continuously and reflect the dynamics of the personality states. According to the most advanced concept of a three-level personality structure according to D. Leontyev, the system of personal meanings is included in the average level of the semantic sphere [1]. It is in personal senses that the meaningful side of a person's relationship with his inner and outer world is accumulated. Two polar strategies are proposed for modeling the processes of semantic regulation. The adaptive strategy of sense formation is a way of organizing the semantic sphere based on the formal and stereotypical goal-setting, aimed at the need to compensate for the developmental deficiencies of the individual by adjusting and uniform movement in the layer of already acquired personal meanings under the influence of the external environment, perceived as dominant and

\footnotetext{
*Corresponding author: godunmv997@gmail.com
} 
determining its vital activity. The developing strategy of sense formation is a way of transforming the semantic sphere oriented to the recognition of motives and generating relevant goals, aimed at creating promising meanings and timely restructuring of their content to realize the possibility of personal growth under the influence of external factors, assessed as surmountable living conditions when an individual determines his activity [2]. By virtue of their regulatory nature, personal meanings are in mutual agreement with personality traits. The manifestation of certain personality traits indicates the presence of appropriate meanings that reflect the current sense-forming strategy.

\section{Materials and methods}

To identify personality profiles of polar semantic strategies, a particular semantic differential in the form of bipolar scales of personality properties has been developed. The scale contains two key opposing personality traits and transitional meanings between them [3]. Using the semantic scales of personality traits, it is possible to identify the features of their manifestation on different plans of human activity. It is known that the value-semantic potential of a person is realized in three main areas: worldview, behavioral and cognitive $[4,5]$. At the same time, in a cognitive sense, a variable development of intellectual abilities is possible, which N. Gardner represents as seven varieties of multiple intelligence [6]. Thus, it is necessary to have nine scales of a particular semantic differential to describe the features of the studied strategies of meaning formation.

In each of the nine scales, the first three words express a developmental strategy, the middle word reflects a neutral state, the last three words express an adaptive strategy [3]:

1) world outlook scale: self-sufficiency - meaningfulness - responsibility - disinterest levity - inadvertence - disorganization;

2) behavioral scale: tranquility - civility - leniency - indifference - bravado impatience - inadequacy;

3) verbal-linguistic scale: eloquence - erudition - originality - conventionality narrowness - categoricity - stereotype;

4) logical-mathematical scale: abstractiveness - systemacy - logicality - linearity inconsistency - fragmentariness - banality;

5) visual-spatial scale: imagery - expressiveness - accuracy - mediocrity - disorder disunity - disproportion;

6) motor-leading scale: vitality - plasticity - mobility - ordinariness - mismatch sluggishness - passivity;

7) musical and rhythmic scale: rhythmicity - musicality - proportion - mediocrity narrowness - obsession - monotony;

8) interpersonal scale: sociability - trustfulness - benevolence - lack of interest hesitation - distrustfulness - isolation;

9) intrapersonal scale: confidence - calmness - attentiveness - unpretentiousness emotionality - irritability - suspiciousness.

Together with the developed private semantic differential nine scales of personal properties, the test "Life-meaning Orientations" by D. Leontiev was used [7]. The test involved $n=145$ people. In the total sample, gradation was carried out by age: young age (18-23 years) 102 people and average age (26-56 years) 43 people; by gender: 33 men and 112 women; by professional attribute: 80 psychology students, 30 historian students, and 35 high school teachers.

\section{Results}

To identify correlation relationships, Pearson pair correlation coefficients are calculated. A 
stable positive statistically significant correlation $(\mathrm{p} \leq .05)$ was found between the parameters of nine developed scales of the private semantic differential of personal properties and the "meaningfulness of life" indicator by D. Leontiev's test (Table 1). Therefore, this indicator is adopted as a marker indicator for identifying polar strategies of sense formation.

Table 1. Statistically significant Pearson linear correlation coefficients (remp) between the marker meaning "meaningfulness of life" and the studied parameters of the scales of the partial meaning differential of personal properties in groups of samples by attributes

\begin{tabular}{|c|c|c|c|c|c|c|c|c|c|}
\hline $\begin{array}{c}\text { Величина } \\
\mathrm{r}_{\text {кр при }} \\
\mathrm{p}=.05\end{array}$ & $\begin{array}{c}1 \\
\text { world } \\
\text { outlook } \\
\text { scale }\end{array}$ & $\mid \begin{array}{c}2 \\
\text { behavio } \\
\text { al scale }\end{array}$ & $\begin{array}{c}3 \\
\text { verbal- } \\
\text { linguistic } \\
\text { scale }\end{array}$ & $\begin{array}{c}4 \\
\text { logical- } \\
\text { mathem } \\
\text { atical } \\
\text { scale }\end{array}$ & $\begin{array}{c}5 \\
\text { visual- } \\
\text { spatial } \\
\text { scale }\end{array}$ & $\begin{array}{c}6 \\
\text { visual- } \\
\text { spatial } \\
\text { scale }\end{array}$ & $\begin{array}{c}7 \\
\text { musical } \\
\text { and } \\
\text { rhythmic } \\
\text { scale }\end{array}$ & $\begin{array}{c}8 \\
\text { interperso } \\
\text { nal scale }\end{array}$ & $\begin{array}{c}9 \\
\text { intrapers } \\
\text { onal } \\
\text { scale }\end{array}$ \\
\hline \multicolumn{10}{|c|}{ Age changes: age from 18 to 23 years $(n=102)$} \\
\hline $\mathrm{r}_{\mathrm{\kappa p}}=0,197$ & 0,322 & 0,259 & 0,227 & 0,203 & 0,221 & 0,387 & 0,454 & 0,409 & 0,313 \\
\hline \multicolumn{10}{|c|}{ Age changes: age from 26 to 56 years $(n=43)$} \\
\hline $\mathrm{r}_{\mathrm{\kappa p}}=0,301$ & 0,341 & 0,327 & 0,328 & 0,309 & 0,571 & 0,397 & 0,408 & 0,319 & 0,507 \\
\hline \multicolumn{10}{|c|}{ Gender changes: women $(n=112)$} \\
\hline $\mathrm{r}_{\mathrm{\kappa p}}=0,187$ & 0,352 & 0,321 & 0,195 & 0,189 & 0,298 & 0,401 & 0,449 & 0,380 & 0,341 \\
\hline \multicolumn{10}{|c|}{ Gender changes: men $(n=33)$} \\
\hline $\mathrm{r}_{\mathrm{Kp}}=0,344$ & 0,373 & 0,350 & 0,466 & 0,362 & 0,365 & 0,358 & 0,449 & 0,526 & 0,513 \\
\hline \multicolumn{10}{|c|}{ Differences by profession: psychology students $(\mathrm{n}=80)$} \\
\hline $\mathrm{r}_{\mathrm{\kappa p}}=0,220$ & 0,355 & 0,337 & 0,278 & 0,258 & 0,227 & 0,381 & 0,401 & 0,369 & 0,356 \\
\hline \multicolumn{10}{|c|}{ Differences by profession: history students $(\mathrm{n}=30)$} \\
\hline $\mathrm{r}_{\mathrm{\kappa p}}=0,364$ & 0,384 & 0,369 & 0,425 & 0,402 & 0,457 & 0,373 & 0,636 & 0,534 & 0,375 \\
\hline \multicolumn{10}{|c|}{ Differences by profession: secondary school teachers $(n=35)$} \\
\hline $\mathrm{r}_{\mathrm{\kappa p}}=0,344$ & 0,369 & 0,354 & 0,359 & 0,436 & 0,578 & 0,413 & 0,399 & 0,380 & 0,683 \\
\hline
\end{tabular}

Using the marker indicator, the sample was divided into two strata. If the respondent has a marker-indicator value greater than the average value in the sample when gradation by attribute, then he refers to a stratum with a developing strategy of meaning formation. If the respondent has a value of the marker indicator less than the average value in the sample when gradation by attribute, then he refers to a stratum with an adaptive strategy of meaning formation. For each stratum that reflects the corresponding strategy, the average scales indicators values of the private semantic differential are determined. These indicators show personality profile parameters for the two polar strategies (Table 2).

Table 2. Settings personal profiles of strategies of meaning-building

\begin{tabular}{|c|c|c|}
\hline Criteria & Developing strategy of meaning-building & Adaptive strategy of meaning-building \\
\hline \multicolumn{3}{|c|}{ Age changes } \\
\hline $\begin{array}{c}\text { age from } 18 \text { to } \\
23 \text { years }\end{array}$ & $\begin{array}{c}\text { responsibility, leniency, originality, logicality, } \\
\text { expressiveness, plasticity, musicality, } \\
\text { benevolence, attentiveness. }\end{array}$ & $\begin{array}{c}\text { disinterest, indifference, } \\
\text { conventionality, logicality, } \\
\text { accuracy, ordinariness, narrowness, } \\
\text { lack of interest, emotionality. }\end{array}$ \\
\hline $\begin{array}{c}\text { age from } 26 \text { to } \\
56 \text { years }\end{array}$ & $\begin{array}{c}\text { meaningfulness, civility, originality, logicality, } \\
\text { expressiveness, plasticity, musicality, }\end{array}$ & $\begin{array}{c}\text { responsibility, civility, originality, } \\
\text { logicality, accuracy, mobility, }\end{array}$ \\
\hline
\end{tabular}




\begin{tabular}{|c|c|c|}
\hline \multicolumn{2}{|c|}{ trustfulness, attentiveness. } & $\begin{array}{c}\text { proportion, trustfulness, } \\
\text { unpretentiousness. }\end{array}$ \\
\hline Women & $\begin{array}{c}\text { meaningfulness, civility, originality, } \\
\text { logicality, expressiveness, plasticity, } \\
\text { musicality, trustfulness, attentiveness. }\end{array}$ & $\begin{array}{c}\text { disinterest, indifference, } \\
\text { conventionality, logicality, } \\
\text { accuracy, ordinariness, narrowness, } \\
\text { lack of interest, emotionality. }\end{array}$ \\
\hline Men & $\begin{array}{c}\text { responsibility, leniency, erudition, logicality, } \\
\text { expressiveness, plasticity, musicality, } \\
\text { trustfulness, calmness. }\end{array}$ & $\begin{array}{c}\text { responsibility, leniency, originality, } \\
\text { logicality, accuracy, mobility, } \\
\text { proportion, hesitation, } \\
\text { unpretentiousness. }\end{array}$ \\
\hline $\begin{array}{c}\text { Psychology } \\
\text { students }\end{array}$ & $\begin{array}{c}\text { responsibility, leniency, originality, logicality, } \\
\text { expressiveness, mobility, musicality, } \\
\text { benevolence, attentiveness. }\end{array}$ & $\begin{array}{c}\text { levity, indifference, } \\
\text { conventionality, logicality, }\end{array}$ \\
\hline $\begin{array}{c}\text { History } \\
\text { students }\end{array}$ & $\begin{array}{c}\text { responsibility, leniency, erudition, logicality, } \\
\text { expressiveness, vitality, rhythmicity, } \\
\text { trustfulness, attentiveness. }\end{array}$ & $\begin{array}{c}\text { mediocrity, mismatch, narrowness, } \\
\text { lack of interest, unpretentiousness. }\end{array}$ \\
\hline $\begin{array}{c}\text { responsibility, leniency, originality, } \\
\text { logicality, accuracy, mobility, } \\
\text { mediocrity, benevolence, } \\
\text { unpretentiousness. }\end{array}$ \\
\hline $\begin{array}{c}\text { Secondary } \\
\text { school teachers }\end{array}$ & $\begin{array}{c}\text { meaningfulness, civility, originality, logicality, } \\
\text { expressiveness, plasticity, musicality, } \\
\text { trustfulness, calmness }\end{array}$ & $\begin{array}{c}\text { meaningfulness, civility, originality, } \\
\text { logicality, accuracy, mobility, } \\
\text { proportion, benevolence, } \\
\text { emotionality. }\end{array}$ \\
\hline
\end{tabular}

\section{Discussions}

The "logicality" parameter manifests itself as common to the personality profiles of both strategies in all three samples by age, gender, and occupational characteristics. In the samples by age and gender for the developing strategy, "expressiveness", "plasticity", and "musicality" are common, while "accuracy" is common for the adaptive one. In a sample based on professional characteristics, a common indicator for a developing strategy is "expressiveness". Identified features may indicate the presence of common grounds in the processes of meaning formation, which reflects the unity of the person's semantic sphere.

\section{Conclusions}

The indicators of the identified personality profiles do not coincide, which shows the presence of acmeological dynamics of the world image, which is influenced by the strategies of experiencing subject's meaning formation. Using the proposed approach in identifying personality profiles, it is possible to establish an actual strategy for the formation of meanings. Using for this the proposed scales of the private semantic differential of personal properties and the indicator-marker "Meaningfulness of life" of the "Life-meaning orientations" test by D. Leontyev seems to be inexpensive in terms of testing.

The study was carried out in the framework of the implementation of the internal grant of SFU No. VnGr-07/2017-01 "Development of technologies for initiating meaning formation as a component of modern communication systems to ensure information security of the Internet".

\section{References}


1. D. Leontiev, Essay on the psychology of personality (Smysl, Moscow, 1997)

2. I. Abakumova, M. Godunov, A. Enin, Z. Generdukaeva. Meaning-building strategies: Modern representations in the works of native researchers (Credo, Moscow, 2016)

3. M. Godunov, The ensemble of personality traits: Interpreting and diagnosing bipolar semantic scales. Book 1 (Credo, Moscow, 2016)

4. S. Dyakov. Herald Of Omsk University. Series: Psychology. 1, 15-33 (2015)

5. V. Kotlyakov, Herald of KemSU. 2 (54), 148-153 (2013)

6. H. Gardner, Frames of Mind: The Theory of Multiple Intelligences (Basic Books, New York, 1983)

7. D. Leontiev, Test life orientations (Smysl, Moscow, 2000) 